\title{
MEMBANGUN MODEL PERSATUAN UMMAT \\ MELALUI PERSPEKTIF ILMU KOMUNIKASI DAKWAH
}

\author{
TAUFIK HIDAYAT \\ taufikx@gmail.com \\ Sekolah Tinggi Ilmu Da'wah Mohammad Natsir, Indonesia
}

\begin{abstract}
ABSTRAK
Tujuan Penelitian: Untuk menganalisis model persatuan umat melalu perspektif Ilmu Komunikasi Dakwah. Metode Penelitian: Kualitatif. Hasil Penelitian: Menyatukan umat Islam ke dalam satu tubuh bukanlah tugas yang mudah seperti seharusnya. Ada banyak metode yang telah dijelaskan oleh Ulama Islam di seluruh dunia untuk menangani masalah ini. Oleh karena itu, penelitian ini mencoba berkontribusi untuk mengatasi masalah tersebut dengan menggunakan perspektif komunikasi dakwah. Makalah ini menggunakan Knapp's Relationship model untuk mengonfigurasi fase-fase pembangunan umat menjadi satu tubuh yang disatukan. Ini juga mengantisipasi faktor-faktor disintegrasi yang dapat membahayakan integrasi. Kasus fakta empiris telah dirujuk sesuai dengan masing-masing fase. Sebagai solusinya, makalah ini menawarkan beberapa kiat konstruktif untuk memulai fase integrasi umat dan semoga akan berhasil seperti yang dijelaskan oleh model.
\end{abstract}

Kata kunci: Model Hubungan, Persatuan Umat, Komunikasi Dakwah

\section{PENDAHULUAN}

Semenjak Rasulullah menyebarkan risalah agama Islam pada 14 abad yang lalu, terdapat sebuah ajaran dalam Islam yang sangat merubah corak pergaulan bangsa Arab jahiliah pada saat itu, yang tadinya mereka hidup secara berkelompok kelompok dan merasa bangga dengannya maka agama Islam menjadikan mereka saling bersatu dalam satu ikatan aqidah Islamiyah.

Sudah mafhum kita ketahui bahwa Allah S.W.T berfirman dalam Al-Qur'an pada QS Ali Imran ayat 103 dengan bunyi :

'Dan berpeganglah keamu semuanya keepada tali (agama) Allah, dan janganlah kamu bercerai berai, dan ingatlah akan nikemat Allab kepadamu ketika kamu dahulu (masa Jahiliyah) bermusub-musuban, maka Allah mempersatukan hatimu, 
lalu menjadilab kamu karena nikmat Allah, orang-orang yang bersaudara; dan kamu telah berada di tepi jurang neraka, lalu Allah menyelamatkan kamu dari padanya. Demikianlah Allah menerangkan ayat-ayat-Nya kepadamu, agar kamu mendapat petunjuk."

Menurut tafsir Ibnu Katsir bahwa sebab ayat ini turun adalah berkenaan dengan suku Aus dan Kharraj yang selalu bermusuhan sebelum Islam datang di Madinah, maka ayat ini memerintahkan mereka untuk bersatu dengan membangun persaudaraan diantara mereka. ${ }^{1}$

Dalam ayat diatas terkandung petunjuk dari Allah S.W.T tentang tiga petunjuk membangun persatuan. Tiga petunjuk tersebut yaitu yang pertama adalah berpegang teguh kepada tali (Agama) Allah, ${ }^{2}$ petunjuk kedua adalah dilarang untuk bercerai berai, petunjuk ketiga adalah mengingat nikmatnya bersaudara dibandingkan bermusuhan. Sehingga dengan dilaksanakannya tiga petunjuk tadi maka Allah menurunkan pertolonganNya dengan mempersatukan hati hati mereka.

Jadi, bersatunya hati bukan karena campur tangan manusia, tetapi Allah yang melakukan intervensi langsung, kita hanya disuruh menjalankan petunjuk sebab sebab persatuan tersebut ${ }^{3}$ sehingga Allah sendiri lah yang akan menyatukan hati hati kita seperti apa yang pernah terjadi dengan kaum Aus dan Khazraj di kota Madinah.

Untuk membahas ketiga petunjuk tersebut tentunya sudah banyak para ulama dan asaatidz yang menguraikan dan membahas dengan perspektif yang saling melengkapi, dalam tulisan ini penulis akan melihatnya dari perspektif komunikasi dakwah dimana perspektif ini hanyalah alat bantu untuk memudahkan dalam menganalisa model taktis persatuan yang mau dibangun.

Komunikasi dakwah dalam bahasa sederhananya adalah komunikasi yang unsur-unsurnya disesuaikan visi dan misi dakwah. Menurut Toto Tasmara bahwa komunikasi dakwah adalah suatu bentuk komunikasi yang khas dimana seseorang komunikator menyampaikan pesan-pesan yang bersumber atau sesuai dengan

${ }^{1}$ Tafsir Ibnu Katsir, PustakaAl-Kautsar: Jakarta, Hal. 234, Jiid3

2Menurut Ibnu Mas'ud, yang dimaksud "taliAllah" adalah Al-Jama'ah, Al-Qurthubi menyatakan, sesungguhnya Allah memerintahkan supaya bersatu padu dan melarang berpecahbelah, karena perpecahan itu adalah kerusakan dan persatuan (Al-Jama'ah) itu adalah keselamatan. (TafsirQurthubiIV/159) SebagianUlama ada yang mengatakan bahwa "taliAllah" itu adalah Dinnullah, menurut sebagian Ulama yang lain; Taat kepada Allah, Ikhlas dalam bertaubat, janjiAllah. Al-Imaam Fakhrur Razi menyimpulkan bahwa seluruh penafsiran tersebut pada hakekatnya saling melengkapi, karena Al-Qur'an, janji Allah, Dinnullah, taat kepada Allah dan Al-Jama'ah dapat menyelamatkan orang yang berpegangteguh dengannya supaya tidak terjatuh ke dalam dasar Neraka Jahannam, maka hal-hal tersebut dijadikan sebagai tali Allah agar mereka berpegangteguh dengannya (TafsirAl-KabirVIII/162163).

${ }^{3}$ Disampaikan oleh KH. Nadjih Ahjad pada taushiyah rakernas Dewan Da'wah di Wisma Agramulya, Puncak Bogor, 21 November 2010 
ajaran al Qur'an dan Sunnah, dengan tujuan agar orang lain dapat berbuat amal shaleh sesuai dengan pesan-pesan yang disampaikan. ${ }^{4}$

Jadi dari segi proses komunikasi dakwah hampir sama dengan komunikasi pada umumnya, tetapi yang membedakan hanya pada cara dan tujuan yang akan dicapai. Adapun tujuan komunikasi pada umumnya yaitu mengharapkan partisipasi dari komunikan atas ide-ide atau pesan-pesan yang disampikan oleh pihak komunikator sehingga pesan-pesan yang disampaikan tersebut terjadilah perubahan sikap dan tingkah laku yang diharapkan, sedangkan tujuan komunikasi dakwah yaitu mengharapkan terjadi nya perubahan atau pembentukan sikap atau tingkah laku sesuai dengan ajaran agama Islam.

Jika kita coba analisa tiga petunjuk dari Allah pada surat diatas melalui perspektif komunikasi dakwah, maka akan kita temukan kesesuaian nya dengan penemuan teori teori modern dalam ilmu komunikasi.

Petunjuk yang pertama, adalah perintah berpegang teguh kepada tali (agama) Allah. Perintah ini bersifat Bina'an (membina / membangun), dimana peran dari kelompok kelompok Islam sangat dibutuhkan dengan cara cara yang aktif konstruktif, artinya setiap pihak yang menginginkan persatuan harus mengambil peran aktif untuk membangunnya melalui jalan berpegang teguh kepada tali (agama) Allah. Jika ada salah satu pihak saja yang bersifat pasif atau tanpa kontribusi dalam membangun persatuan maka dapat dikatakan usaha tersebut akan jauh dari keberhasilan.

\section{METODE PENELITIAN}

Untuk membantu kita dalam menggambarkan (Modelling) tahapan membangun ukhuwah tersebut sebuah model dalam ilmu komunikasi yang disebut Knapp's Relationship Model ${ }^{5}$ bisa kita gunakan untuk menggambarkan bagaimana hubungan antar manusia dapat berakhir dengan sebuah persatuan yang kuat (Bonding). Mark L Knapp membagi tahapan hubungan antar manusia menjadi lima tahapan menuju integrasi dan lima tahapan hubungan antar manusia yang menuju perpecahaan.

${ }^{4}$ TotoTasmara, Komunikasi Dakwah (Jakarta:GayaMediaPratama,1997), hal.9.

5"Knapp'sRelationshipModel".http:// communicationtheory.org.CommunicationTheory.Retri eved23October2014. 


\section{Diagram 1. Model Knapp's Relationship Model}

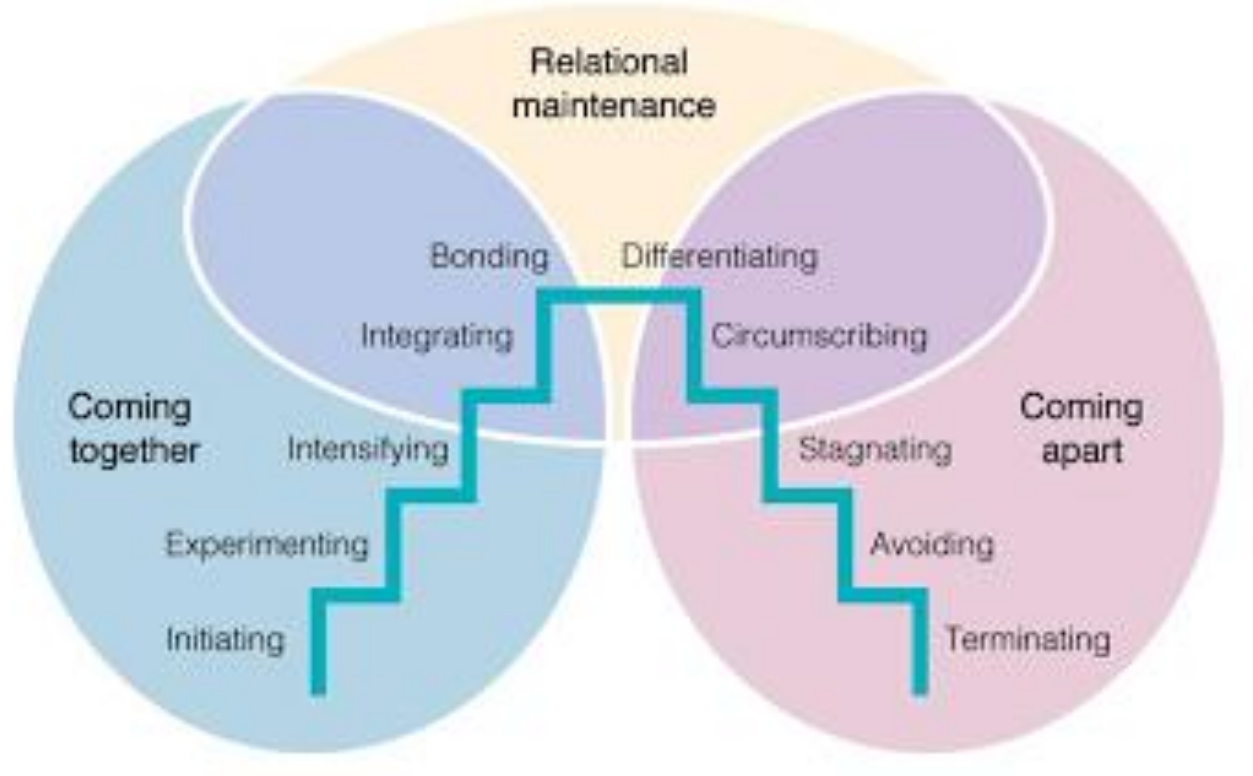

\section{Knapp's Staircase Model}

Stages of Relational Development

Sumber

:"Knapp'sRelationshipModel".http://communicationtheory.org. Communicati onTheory.Retrieved23October2014.

\section{HASIL DAN DISKUSI}

Kita akan fokus dulu membahas lima tahap menuju integrasi sebelum membahas tahapan menuju perpecahaan. Tahap pertama dalam menuju persatuan adalah Initiating pada tahap ini setiap orang hanya berusaha menjaga penampilan tampak luar saja dimana masing masing ingin menampilkan kesan baik dimata orang yang baru dikenal. Pada tahap ini belum terjadi kesadaran untuk saling terikat sebagai saudara, sahabat atau pasangan hidup. Kita sering berada pada posisi ini ketika baru berkenalan dengan orang lain. Pembicaraan baru berupa tegur sapa menanyakan kabar atau hal remeh temeh. 
Tahap Kedua adalah Experimenting, pada tahap ini dimulai eksplorasi perkenalan secara umum, biasanya terkait dengan isu isu yang sama sama disukai atau sama sama dibenci, pembicaraan masih terkait dengan hal hal diluar dari urusan pribadi, pada tahap ini biasanya akan ditentukan apakah sebuah hubungan akan dilanjutkan atau dihentikan, karena pada tahap ini sudah mulai terlihat visi dan misi masing masing dari isu isu yang dibicarakan.

Tahap Ketiga adalah Intensiffing, pada tahap ini suasana sudah mulai akrab dan terkesan tidak formal, masing masing pihak sudah mulai mengungkap identitas pribadi masing masing dimana untuk memperkuat hubungan biasanya akan sering terjadi saling balas kunjungan, memberikan hadiah maupun saling melakukan aktivitas bersama sehingga hubungan akan semakin intensif dan berkualitas.

Tahap keempat adalah Integrating, pada tahap ini adalah tahap integrasi atau penyatuan dimana kedua belah pihak sudah saling mengenal secara luar dalam tentang kepribadian seseorang, tidak ada lagi hal - hal yang ditutupi. Kalau dalam kehidupan sehari hari biasanya kita akan lihat mereka sebagai saudara, sahabat dekat atau sepasang kekasih.

Tahap kelima adalah Bonding tahap ini adalah tahap dimana orang orang yang tadi sudah menyatu akan mendeklarasikan diri mereka didepan orang banyak bahwa mereka sudah bersatu atau dalam hubungan sepasang kekasih adalah pernikahan. Tahap ini seringkali berupa formal legal, dimana terjadi pencatatan dokumen yang menunjukkan adanya hubungan kedua pihak dan diketahui oleh semua orang.

Dari kelima tahap diatas, kita dapat berkaca ditahap mana posisi ummat Islam di Indonesia sekarang yang direpresentasikan melalui ormas maupun kelompok kelompk Islam, pada tahap Iniating, kelompok kelompok dalam ummat Islam sudah saling tegur sapa dan berusaha untuk melakukan perkenalan dengan banyaknya forum forum silaturrahim, sehingga nampaknya tahap iniating ini sudah dilalui, pada tahap Experimenting dimana tokoh tokoh ummat Islam juga sudah mulai membicarakan masalah masalah isu bersama yang terkait permasalahan ummat seperti masalah masalah ekonomi ummat, sosial dan politik, masing masing sedang mulai memahami visi dan misi masing masing kelompok walaupun belum secara utuh dapat diserap oleh kelompok lainnya karena terkadang terhalang oleh adanya perbedaan pilihan politik, pemahaman agama yang masih berbeda dan kepentingan kepentingan lainnya.

Jadi, pada tahap experimenting ini masih terjadi pergumulan untuk memahami visi dan misi masing masing kelompok. Terkadang visi dan misi masing masing kelompok itu tidak hanya bisa dibaca dari apa yang tersurat tetapi juga yang tersirat. Sebagai contoh misalnya, sudah mafhum bagi kita ekspresi kecintaan para kaum Nahdiyin kepada Rasulullah kerapkali diwujudkan dalam acara Maulid Nabi sebaliknya kelompok Islam lain melihat hal tersebut sebagai 
ritual yang Bid'ah. Padahal kedua kelompok yang saling berbeda ini tentunya sama sama mencintai Rasulullah dalam ekspresi cara yang berbeda. Jika kelompok anti-maulid bisa berempati terhadap perasaan kaum Nahdiyin yang mencintai Nabi dengan metode maulid tersebut tentunya vonis Bid'ah tidaklah cara komunikasi yang etis. Sebaliknya, kelompok pro-maulid jika mau ber-empati terhadap kelompok yang tidak melaksanakan Maulid karena khawatir jatuh kedalam bid'ah tentunya vonis seperti wahabi, radikal, teroris dll bukanlah cara komunikasi yang etis pula. Terkadang menahan diri untuk tidak menyampaikan sesuatu sudah cukup untuk bisa melanjutkan ke tahap berikutnya yaitu tahap Intensifying. Tentunya vonis yang ditahan tadi bisa disampaikan ketika sudah tahap Integrating dalam rangka saling menasehati dalam kebenaran dan kesabaran, dimana pada tahap ini hubungan sudah cair dan informal sehingga komunikasi bisa disampaikan layaknya teman sepermainan pada masa kecil yang penuh senda gurau dan keakraban.

Dengan demikian, tahap experimenting ini perlu diselesaikan terlebih dahulu sebelum bisa masuk ketahap selanjutnya yang membutuhkan syarat syarat yang lebih kompleks.

Petunjuk yang kedua adalah perintah Allah yang bersifat Difa'an (Preventif), dimana ummat Islam dilarang untuk berpecah belah, merujuk dari Knapp's Relationship Model tadi maka terdapat juga lima tahap hubungan manusia yang dapat berakhir pada perpecahan atau disintegrasi. Tahap ini akan terjadi jika kita tidak mampu merawat hubungan yang tadi sudah memasuki tahap Bonding.

Tahap pertama dari sebuah perpecahan adalah Differentiating pada tahap ini hubungan antar individu atau kelompok mulai menunjukkan adanya ketidakharmonisan ditandai dengan berbeda pendapat dalam beberapa hal atau isu kemudian tidak lagi melibatkan sahabat, saudara atau pasangannya untuk berpikir terhadap sesuatu hal terkadang hal ini disebabkan oleh godaan dari luar yang bisa jadi berupa iming iming kekuasaan/jabatan atau uang. Sehingga pada tahap ini aktivitas yang tadinya dilakukan bersama sudah mulai berkurang.

Tahap kedua dalam perpecahan adalah tahap Circumscribing, pada tahap ini kedua belah pihak sudah mulai membatasi percakapan terhadap tema tema yang dianggap akan terjadi perdebatan, masing masing pihak sudah merasa pendapatnya tidak bisa dibantah lagi oleh saudara atau sahabatnya. Masing masing pihak sudah mempunyai aktivitas sendiri sendiri yang sama sekali tidak diketahui oleh saudaranya atau sahabatnya.

Tahap ketiga dalam perpecahan adalah tahap Stagnating, pada tahap ini masing masing pihak sudah tau bahwa mereka sudah sulit bersama sama tetapi karena masih terhalang oleh adanya kepentingan yang lebih besar maka keduanya menahan diri untuk berpecah belah. Pertemuan atau pembicaraan sangat jarang 
sekali. Hubungan keduanya menjadi kaku atau dingin sehingga jika ada pembicaraan hanya hal - hal penting saja.

Tahap keempat adalah Avoiding, di tahap ini lah komunikasi sudah benar benar terputus, karena masing masing pihak berusaha untuk menghindar bertemu secara fisik, sehingga tidak ada lagi cara untuk mendamaikan keduanya karena pintu persatuan atau persaudaraan sudah benar benar putus. Dan tahap terakhir adalah masing masing pihak sudah meninggalkan komitmen persatuan dimana masing masing pihak akan mengambil jalan masing masing untuk mencari persaudaraan atau persahabatan baru dengan pihak lain.

Petunjuk pada ayat ini bersifat preventif dimana Allah memerintahkan agar supaya kita juga menghindari sebab sebab perpecahan tersebut. Mungkin saja ada diantara kelompok kelompok ummat Islam yang mulai berada pada tahap awal dari sebuah perpecahan yaitu Differentiating, jika tidak segera melakukan Tabayyun atau klarifikasi maka tahap selanjutnya akan dapat terjadi. Oleh sebab itu, banyak sekali tuntutan Allah agar kita jangan sampai masuk dalam wilayah Differentiating ini seperti selalu Tabayyun langsung jika ada berita yang tidak jelas atau sumbernya dari orang fasik (QS. Al-Hujurot : 6), ada juga perintah agar kita tidak mengolok olok saudara kita (QS. Al-Hujurot : 11), dilarang untuk banyak berbantah bantahan (debat kusir) karena hal ini akan memperlemah ummat Islam (QS. Al-Anfaal : 46) dan masih banyak tuntutan lain yang bersumber dari Assunnah berkaitan dengan menghindari perbedaan di kalangan ummat ini.

Terakhir adalah petunjuk yang ketiga tentang perintah Allah kepada ummat Islam untuk mengingat nikmat yang diberikanNya atas rasa persatuan tersebut, maka ayat ini menyuruh ummat Islam selalu bersyukur tentang nikmat tersebut dengan maksud untuk selalu merawat persatuan (Relational Maintenance).

Merujuk pada Knapp's Relations Model tersebut maka lima tahap untuk menuju persatuan harus dijaga atau dirawat jika sudah mencapai tahap ke lima yaitu tahap Bonding sehingga tidak mulai memasuki tahap awal dari sebuah perpecahan yaitu Differentiating. Oleh sebab itu, penggalan ayat ini merupakan ayat yang menyuruh ummat Islam untuk merawat persatuan dengan jalan mengingat betapa nikmatnya sebuah persatuan tersebut sehingga timbul lah rasa bersyukur yang dimanifestasikan dalam bentuk menjaga persatuan yang sudah twerwujud. Banyak sekali tuntutan Al-Qur'an dan As-sunnah untuk menjaga sebuah persatuan seperti misalnya selalu mendamaikan (Ishlah) saudara yang sedang bertikai (QS. Al-Hujurot : 10), tuntunan nabi pentingnya melakukan silaturrahim sehingga terjaga persaudaraan dsb. 


\section{KESIMPULAN DAN SARAN}

Dengan mencoba menggunakan tahapan hubungan antar manusia yang menuju persatuan maupun yang perpecahan menurut Knapp's Relationship Model maka kita dapat menguraikan secara lebih terstruktur problematika persatuan ummat khusunya di Indonesia. Kita baru pada tahap Experimenting dalam menuju persatuan ummat dimana kita baru mulai memahami visi misi masing masing kelompok dalam ummat Islam. Oleh sebab itu dibutuhkan usaha oleh seluruh komponen ummat Islam untuk dapat mau menyatukan ummat Islam agar dapat menuju persatuan ummat yang sebenarnya.

Tentunya model persatuan ummat yang menggunakan pendekatan diatas hanyalah alat bantu dalam memudahkan langkah langkah persatuan ummat sehingga momentum persatuan melalui gerakan 212 yang lalu dapat segera di follow up dengan langkah langkah yang lebih konkret dan sistematis. Semoga ada alat alat bantu lain yang secara teoritis bisa kita gunakan demi persatuan ummat di Indonesia. Wallahu'alam Bishowab. 


\section{DAFTAR PUSTAKA :}

Tafsir IbnuKatsir, (Jakarta :PustakaAl-Kautsar. 2001)

Knapp, Mark,

"Knapp'sRelationshipModel".http://communicationtheory.org. Communicatio nTheory. 2008.

Tasmara, Toto, KomunikasiDakwah (Jakarta: Gaya Media Pratama,1997)

73 | Jurnal Dakwah | Vol.1 No.1 |2018 